\title{
Study of Ti, V and Their Oxides-Based Thin Films in the Search for Hydrogen Storage Materials
}

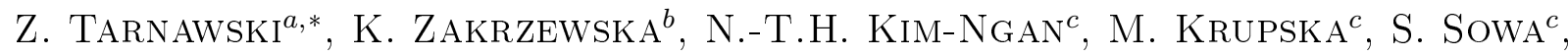 \\ K. DrogowskA ${ }^{a}$, L. HAVElA ${ }^{d}$ AND A.G. BALOGH ${ }^{e}$ \\ ${ }^{a}$ Faculty of Physics and Applied Computer Science, AGH University of Science and Technology, \\ al. A. Mickiewicza 30, 30-059 Kraków, Poland
}

${ }^{b}$ Faculty of Computer Science, Electronics and Telecommunication, AGH University of Science and Technology, al. A. Mickiewicza 30, 30-059 Kraków, Poland

${ }^{c}$ Institute of Physics, Pedagogical University, 30-084 Kraków, Poland

${ }^{d}$ Faculty of Mathematics and Physics, Charles University, Ke Karlovu 5, 12116 Prague, Czech Republic

${ }^{e}$ Institute of Materials Science, Technische Universität Darmstadt, 64287 Darmstadt, Germany

(Received January 24, 2015; in final form July 6, 2015)

Thin film series consisting of $\mathrm{Ti}, \mathrm{V}, \mathrm{TiO}_{2}$ and $\mathrm{V}_{2} \mathrm{O}_{5}$ layer with different layer geometries, sequences and thicknesses have been prepared by the sputtering technique. The hydrogen depth profile of selected films upon hydrogen charging at 1 bar and/or hydrogenation at pressure up to 102 bar was determined by using secondary ion mass spectrometry and nuclear reaction analysis using a N-15 beam. The highest hydrogen storage with a concentration up to 50 at.\% was found in the pure $\mathrm{Ti}$ and $\mathrm{Ti}$-contained layer, while it amounts to around $30 \%$ in the metallic $\mathrm{Ti}-\mathrm{V}-\mathrm{Ni}$ layer. Hydrogen can diffuse through the $\mathrm{TiO}_{2}$ layer without accumulation, but can be stored in the $\mathrm{VO}_{2}$ layer in some cases. Hydrogen can remove the preferential Ti orientation in the films and induce a complete transition of $\mathrm{V}_{2} \mathrm{O}_{5}$ into $\mathrm{VO}_{2}$ in the films.

DOI: 10.12693/APhysPolA.128.431

PACS: 81.15.Cd, 68.49.-h, 61.05.C-, 68.60.-p

\section{Introduction}

Hydrogen has been generally accepted as a fuel in the future. Both expiration of fossil fuels and the greenhouse effect threatening the development of human civilization make us consider other efficient and renewable energy sources especially with lacking the negative impact on environment. The hydrogen-based energy systems offer potential solutions. It brings up the search for optimal hydrogen-storage materials which could have much higher volume densities than pressurized and/or liquid hydrogen.

Some metals and their alloys can absorb a large amount of hydrogen and release it easily again upon heating. Such reversible hydrogen reaction systems, the socalled metallic hydrides (or metal hydrides), are potential hydrogen storage media. As an example, the most widely utilized metal hydride today is $\mathrm{LaNi}_{5} \mathrm{H}_{6}$ having the volumetric hydrogen density of $115 \mathrm{~kg} / \mathrm{m}^{3}$, which is much higher than that of liquid hydrogen $\left(70.85 \mathrm{~kg} / \mathrm{m}^{3}\right.$ below $20 \mathrm{~K}$ ). The $\mathrm{MgH}_{2}$ is considered to have a highest gravimetric density of $7.6 \mathrm{wt} \% \mathrm{H}$. (Gravimetric density of $\mathrm{LaNi}_{5} \mathrm{H}_{6}$ is of $1.3 \mathrm{wt} \% \mathrm{H}$.) [1, 2]. Moreover, the advantage of metal hydrides is that they are stable and can be maintained at room temperature (while the liquid hydrogen has to be maintained at low temperature $T=20 \mathrm{~K}$ ).

*corresponding author; e-mail: tarnawsk@agh.edu.pl
The search for hydrogen storage materials brings up the important issues for fundamental research, e.g. understanding the mechanism involved in the interaction of hydrogen with matter in the solid-state form. Introduction of hydrogen into the crystal lattice brings a relatively small perturbation to the system (e.g. the lattice expansion, the crystal and electronic structure modification, the hydrogen bonding with other atoms in the lattice), the new-formed hydrides often exhibiting new and fascinating physical properties. Besides, experimental results show that the kinetics of hydriding and dehydriding of metals and alloys can be improved by the nanostructured form. For instance, faster hydrogen sorption rates were found for the nanocrystalline $\mathrm{Mg}_{2} \mathrm{Ni}$ than that of their bulk counterpart due to an enhanced surface effect and a shortened diffusion path [3]. On the other hand, a reduction of the grain size in $\mathrm{MgH}_{2}$ can decrease the reversible storage capacity related to a reduction of intragrain volume [4] as well as alter the stability due to a decrease of desorption energy [5].

We are interested in the hydrogen storage ability and the effect of hydrogen sorption on the crystal and electronic structure and physical properties of $\mathrm{Ti}, \mathrm{V}$ and their oxides-based thin films. Thin film processing is in fact an alternative method that synthesizes nanostructured materials in specific compositions which could provide a sizereduction to the nanoscale. Besides, it provides a possibility to investigate the surface or interface contributions to the hydrogenation thermodynamics. Numerous thin films with different layer structures and layer sequences 
and layer thicknesses have been prepared by means of sputtering technique and investigated. This work is a review of our results obtained on 3 different film systems: (1) the Ti- and $\mathrm{TiO}_{2}$-based thin films, (2) the $\mathrm{TiO}_{2^{-}}$and $\mathrm{VO}_{x}$-based thin films and (3) the Ti-V films with Ni doping. All the deposited films in the as-deposited state have been investigated thoroughly. Then some selected films were chosen for the hydrogenation experiments. We expect to get some understanding of the role of the atom mixing and diffusion across the film interfaces and precipitation of nanoparticles on the hydrogen absorption rate as well as the reversible effect of the hydrogenation on the thermodynamic properties of the films, in particular the hydrogen storage in the films under different conditions. Details of the experiments and the main outcome of our study are presented in the next sessions.

\section{Experimental methods}

Thin films consisting of $\mathrm{Ti}, \mathrm{TiO}_{2}$ and $\mathrm{VO}_{x}$ with different layer geometry, sequences and layer-thicknesses and the mixed $\mathrm{Ti}-\mathrm{V}-\mathrm{Ni}$ layers have been deposited by means of magnetron dc pulse sputtering system. Si(111), silica $\mathrm{SiO}_{2}$ and/or C-foil substrates for film deposition were placed on a rotatable holder so that up to 8 samples could be obtained in one deposition cycle without breaking the vacuum condition [6]. The high purity $\mathrm{Ti} / \mathrm{V}$ target $(4 \mathrm{~N})$ was sputtered either in a high purity argon (for $\mathrm{Ti} / \mathrm{V}$ layer deposition) or in a controlled $\mathrm{Ar}+\mathrm{O}_{2}$ reactive gas atmosphere (for $\mathrm{TiO}_{2} \mathrm{VO}_{x}$ layer deposition). Our analysis of all investigated layers indicate that only $\mathrm{TiO}_{2} \mathrm{ru}-$ tile form is present, while several vanadium oxide forms $\left(\mathrm{V}_{2} \mathrm{O}_{5}, \mathrm{VO}_{2} \ldots\right)$ can exist. For $\mathrm{Ti}-\mathrm{V}$ and $\mathrm{Ti}-\mathrm{V}-\mathrm{Ni}$ thin film deposition, vanadium and nickel plates were placed on titanium target. Prior to the deposition, the covered $\mathrm{Ti} / \mathrm{Ni}$ portion on the $\mathrm{Ti}$ surface were estimated to get a selected $\mathrm{Ti}-\mathrm{V}$ or $\mathrm{Ti}-\mathrm{V}-\mathrm{Ni}$ ratio in the film.

Some film series have been subjected to hydrogen charging at atmospheric atmosphere (1 bar) and at $300{ }^{\circ} \mathrm{C}$ (in a self-made gas charging system). They were charged with hydrogen once or twice. Each charging was for $3 \mathrm{~h}$. For high-pressure hydrogenation experiments, the films were put into the hydrogenation apparatus with applied hydrogen pressure up to 102 bar and at room temperature (in the high pressured reactor with $\mathrm{LaNi}_{5} \mathrm{H}_{6}$ container).

For investigating of the possibility of enhancement of hydrogen storage, one series of films was subjected for an additional $\mathrm{Pd}$ covering by molecular beam epitaxy (MBE) technique.

We notice here that we prepared and used many different series of films. Our investigations indicated that very similar films were obtained under the same technical conditions. The film chemical composition, depth profile, layer thickness and structure of chosen films after depositions were determined by combined analysis of $\mathrm{X}$-ray diffraction (XRD), X-ray reflectometry (XRR), the Rutherford backscattering (RBS) and optical spectrometry. Details of such investigations have been published earlier [7]. For the films subjected to hydrogenation, the RBS have been performed on each film before and after each hydrogenation. The $\mathrm{He}^{+}$ion beam with energy of 1.6-2.0 MeV and the scattering angle of $171^{\circ}$ were employed for the RBS measurements [8,9]. The computer code SIMNRA was used for data analysis. The direct outcome from RBS spectrum is the $N t$ product, i.e. the areal density (the number of target atoms per unit area). In order to compare the layer-thickness determination from different methods, we evaluated the layer thickness in $\mathrm{nm}(d)$ from RBS data using the mass density determined from XRR for pure layer or the bulk values for the mixed layers. The values of $d$ are converted from the analyzed ( $N t$ ) values (in $10^{15}$ atoms $/ \mathrm{cm}^{2}$ ) using the scaling factor or the conversion coefficient and estimated percentage $(\%)$ of each element in the layers. For instance, for the pure metal layer, $d$ was estimated as

$$
d[\mathrm{~nm}]=k(N t)\left[10^{15} \text { at. } / \mathrm{cm}^{2}\right],
$$

where $k$ is the conversion coefficient for the areal density of $1 \times 10^{15}$ at. $/ \mathrm{cm}^{2}$ for a layer thickness of $1 \mathrm{~nm}$ $\left(10^{-7} \mathrm{~cm}\right) . \quad k=0.175$ and 0.141 , respectively, for $\mathrm{Ti}$ and $\mathrm{V}$, using the bulk values for the mass density $\left(\rho(\mathrm{Ti})=4.51 \mathrm{~g} / \mathrm{cm}^{3}, \rho(\mathrm{V})=6.00 \mathrm{~g} / \mathrm{cm}^{3}\right)$. In our calculations, $k$ alters a little when using the experimentally determined values from XRR for the mass density. For the mixed layer, $d$ was estimated as summation of different layer thickness in which different conversion coefficients were used accordingly to the layer composition. For instance, for a layer consisting of $85 \% \mathrm{TiO}_{2}, 10 \% \mathrm{VO}_{2}$ and $5 \% \mathrm{SiO}_{2}, d$ was estimated as

$$
d[\mathrm{~nm}]=(m 0.85+n 0.10+p 0.05)(N t)\left[10^{15} \mathrm{at} . / \mathrm{cm}^{2}\right],
$$

where $m, n, p$ are the corresponding conversion coefficients estimated using the bulk density of different oxides $\left(\rho\left(\mathrm{TiO}_{2}\right)=4.23 \mathrm{~g} / \mathrm{cm}^{3}, \rho\left(\mathrm{VO}_{2}\right)=4.57 \mathrm{~g} / \mathrm{cm}^{3}\right.$, $\rho\left(\mathrm{V}_{2} \mathrm{O}_{5}\right)=3.36 \mathrm{~g} / \mathrm{cm}^{3}$ and the corresponding values respectively are $m=0.105, n=0.101$ and $p=0.128$ ).

Due to small quantities of hydrogen involved, classical methods such as volumetric and gravimetric techniques are not applicable to thin films. Hydrogen concentration in the films and hydrogen profile were determined by means of a secondary ion mass spectroscopy (SIMS) and nuclear reaction analysis using the ${ }^{15} \mathrm{~N}$ beam $\left({ }^{15} \mathrm{~N}-\mathrm{NRA}\right.$ method). SIMS was carried out by using $\mathrm{Cs}^{+}$primary ions recording positive secondary ions by a CAMECA ims 5f equipment. The reaction ${ }^{15} \mathrm{~N}+{ }^{1} \mathrm{H} \rightarrow{ }^{12} \mathrm{C}+\alpha+\gamma$ $(4.965 \mathrm{MeV}$ ) at a resonance energy of $6.417 \mathrm{MeV}$ (denoted as ${ }^{1} \mathrm{H}\left({ }^{15} \mathrm{~N}, \alpha, \gamma\right){ }^{12} \mathrm{C}$ reaction $)$ was used for the ${ }^{15} \mathrm{~N}-\mathrm{NRA}$ method to obtain the results. The computer code SRIM was used for data evaluation.

\section{Hydrogen storage in $\mathrm{Ti}-\mathrm{TiO}_{2}$ thin films}

$\mathrm{TiO}_{2}$ powders have been widely used as white pigments from ancient times. Since the discovery by Fujishima and Honda in 1972 of water splitting into hydrogen and oxygen on $\mathrm{TiO}_{2}$ electrodes in a photoelectrochemical (PEC) 
cell [10], titanium dioxide has become the most studied among photocatalytic materials [11] for applications in photocatalysis [12], solar cells [13], gas sensors [14]. The results of scientific works in this field were published in thousands papers including many reviews and monographs [15-17]. However, $\mathrm{TiO}_{2}$ has one disadvantage: it is an insulator with a large band gap $(3.2 \mathrm{eV}$ for anatase - the most photoactive phase of $\mathrm{TiO}_{2}$ ) and it only absorbs the ultraviolet light [18], which is contained only about $3 \%$ in a solar spectrum and the energy conversion efficiency (ECE) in the PEC cell was at the level of $\approx 0.5 \%$. Thus the enthusiasm in the research of the solar hydrogen (hydrogen production using solar energy) was over in the middle of the 1980s and the research shifted to the utilization of $\mathrm{TiO}_{2}$ for e.g. the photodegradation of pollutants under sunlight illumination.

One of the major challenges in photocatalytic research is to increase the spectral sensitivity of photocatalysts to the visible light regime, i.e. the largest part of solar radiation. An increased interest has been focused on wide-band gap semiconductor $\mathrm{TiO}_{2-x}$ (i.e. with a small departure $(x \neq 0)$ from the stoichiometric composition) and anion-doped and cation-doped $\mathrm{TiO}_{2}$ [19-21]. It is desirable that the band gap of the semiconductor is near that for the optimum utilization of solar energy, which would be about $1.35 \mathrm{eV}$ [22]. The search is also focused in modifying properties to increase the ECE to the required level for commercialization [23, 24]. Moreover, the interest in $\mathrm{TiO}_{2}$ is concerned to the development of its nanostructure forms (nanoparticles, nanotubes, nanorods, etc.) for renewable energy sources and hydrogen economy, e.g. hydrogen production, detection and even storage [17, 22-28]. For example, 2 wt $\%$ of hydrogen storage in $\mathrm{TiO}_{2}$ nanotubes by hydrothermal process was reported [25]. The sorption of hydrogen was found between the layers of the multilayered wall of $\mathrm{TiO}_{2}$ nanotubes [29]. The $\mathrm{Al} / \mathrm{V}$-doped $\mathrm{TiO}_{2}$ nanofilms [30] and Ni-doped $\mathrm{TiO}_{2}$ nanotubes [31] show great a potential for use as a hydrogen sensor.

We have first investigated the hydrogen absorption in the $\mathrm{Ti}-\mathrm{TiO}_{2}$ film system. Numerous single-, bi- and trilayer films with different layer-thickness consisting of $\mathrm{Ti}$ and $\mathrm{TiO}_{2}$ layer were deposited on $\mathrm{Si}(111)$ and $\mathrm{C}$-foil substrates. Prior to the hydrogen experiments, the film structures and properties of as-sputtered film series were thoroughly investigated and reported in our publications $[7,32,33]$. The obtained results indicated that:

- a compact Ti layer with a strong preferred orientation with (00.1) plane could be always grown on the well-defined (111) plane of Si wafer without interdiffusion at the $\mathrm{Ti} / \mathrm{Si}$ interface,

- $\mathrm{TiO}_{2}$ layer exhibits columnar structure and there is always some small interdiffussion (intergrowth) between the $\mathrm{Ti}$ and $\mathrm{TiO}_{2}$ layers.

Hydrogen storage in $\mathrm{Ti}-\mathrm{TiO}_{2}$ systems have been thoroughly investigated on selected films series and reported in our previous publications $[32,33]$. The main outcome of our investigated were summarised as follows:

- a high hydrogen concentration (storage), up to 50 at.\%, was obtained for the pure Ti layers,

- additional Pd layer enhances the hydrogen storage in the Ti films,

- no hydrogen accumulation was found in the $\mathrm{TiO}_{2}$ layer,

- a large hydrogen storage upon applying a high hydrogen pressure (100 bar) in the thick Ti film (with layer-thickness $>240 \mathrm{~nm}$ ) could lead to a large swelling effect,

- high hydrogen pressure destroys the preferential orientation of the Ti films.

As an example, we show in Fig. 1 the hydrogen profile determined by ${ }^{15} \mathrm{~N}-\mathrm{NRA}$ for the $\mathrm{Ti} / \mathrm{TiO}_{2} / \mathrm{Ti} / \mathrm{Si}(111)$ films revealing the large hydrogen storage up to 40-50 at.\% and the role of $\mathrm{Pd}$ as a catalyst for hydrogen absorption. More detailed interpretation of our results can be found in our previous publication [34].

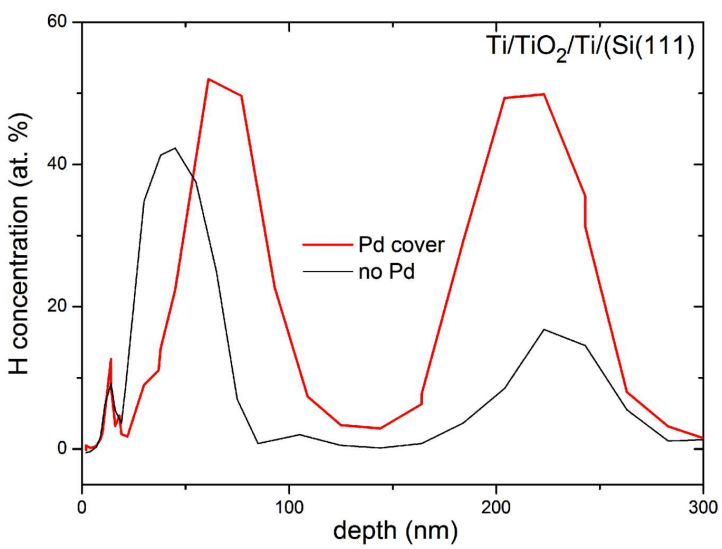

Fig. 1. Hydrogen profile determined by ${ }^{15} \mathrm{~N}-\mathrm{NRA}$ for the $\mathrm{Ti} / \mathrm{TiO}_{2} / \mathrm{Ti} / \mathrm{Si}(111)$ film without covering $\mathrm{Pd}$ and with $\mathrm{Pd}$ cover revealing a large hydrogen storage in the $\mathrm{Ti}$ layers and the storage enhancement due to Pd presence.

\section{4. $\mathrm{V}_{2} \mathrm{O}_{5}-\mathrm{VO}_{2}$ transition assisted by hydrogen in $\mathrm{TiO}_{2}-\mathrm{V}_{2} \mathrm{O}_{5}$ thin films}

Vanadium oxides family is one of the most widely investigated multifunctional materials microelectronics and sensor applications for electrooptical and electrochemical device applications. Vanadium dioxide $\left(\mathrm{VO}_{2}\right)$ has been intensively studied for its metal-insulator phase transition that occurs at a technologically useful temperature of $67^{\circ} \mathrm{C}$. Vanadium pentoxide $\left(\mathrm{V}_{2} \mathrm{O}_{5}\right)$ has also been studied for its electrochromic and thermochromic 
properties. $\mathrm{V}_{2} \mathrm{O}_{5}$ thin films can be applied in electrochromic and electrochemical devices [35] and microbatteries [36]. A large interest is focusing on investigations of $\mathrm{TiO}_{2}-\mathrm{V}_{2} \mathrm{O}_{5}$ thin films to gain the optimal electrochromic properties due to their potential applications for electrochromic smart windows and other electrochemical devices [37]. The interaction of $\mathrm{V}_{2} \mathrm{O}_{5}$ with other oxides would strongly affect its structural properties and reactivity, e.g. $\mathrm{V}_{2} \mathrm{O}_{5}$ dispersion could occur on $\mathrm{TiO}_{2}$ support [38]. The promoting effect of a titanium oxide support on the catalytic properties of vanadium oxide is widely recognized [39]. Investigations of thermochromic properties have revealed that $\mathrm{VO}_{2}-\mathrm{TiO}_{2}$ multilayers have a higher luminous transmittance than that of a single $\mathrm{VO}_{2}$ film and could yield a large change of solar transmittance at both temperatures below and above semiconductor-metal transition temperature $(\approx 340 \mathrm{~K})$ of $\mathrm{VO}_{2}[40]$.

We are interested in the hydrogen effect on the structure and properties of $\mathrm{TiO}_{2}-\mathrm{V}_{2} \mathrm{O}_{5}$ thin films as well as the hydrogen storage ability in this system. Since the surface layer was defined as the stoichiometric $\mathrm{V}_{2} \mathrm{O}_{5}$ and/or $\mathrm{TiO}_{2}$ layer, for a simplicity, we use such a layer composition for the film notation, e.g. $\mathrm{TiO}_{2} / \mathrm{V}_{2} \mathrm{O}_{5} / \mathrm{SiO}_{2}$ and $\mathrm{V}_{2} \mathrm{O}_{5} / \mathrm{TiO}_{2} / \mathrm{SiO}_{2}$. The estimated film composition for the layer was discussed in detail in each case. Prior to the hydrogenation experiments, we have studied thoroughly the properties of layered structures of numerous films consisting of $\mathrm{V}_{2} \mathrm{O}_{5}$ and $\mathrm{TiO}_{2}$ layer, in particular their interface properties [41]. The obtained results on these films are summarized as follows:

- If one starts first with titanium oxide deposition and then continues with vanadium oxide deposition, once would not get a stoichiometric $\mathrm{TiO}_{2}$ layer. Instead, due to both $\mathrm{V}$ - and $\mathrm{Si}$ diffusion, the $\mathrm{TiO}_{2}$ layer consists a small amount of $\mathrm{SiO}_{2}$ and $\mathrm{VO}_{2}$ and thus forming a mixed dioxide $\left(\mathrm{MO}_{2}\right.$ where $\mathrm{M}=\mathrm{Ti}, \mathrm{V}, \mathrm{Si}$ ) layer on the substrate. However, on the film surface is the stoichiometric $\mathrm{V}_{2} \mathrm{O}_{5}$ layer. The correct film composition should be $\mathrm{V}_{2} \mathrm{O}_{5} / \mathrm{MO}_{2} / \mathrm{SiO}_{2}$ (instead of the nominal one $\left.\mathrm{V}_{2} \mathrm{O}_{5} / \mathrm{TiO}_{2} / \mathrm{SiO}_{2}\right)$.

- In the case if the opposite deposition sequence was chosen, i.e. first the vanadium and then the titanium oxide deposition, the film consists of both stoichiometric $\mathrm{V}_{2} \mathrm{O}_{5}$ and $\mathrm{TiO}_{2}$ layers. Moreover, a sharp interface at the film-substrate $\left(\mathrm{V}_{2} \mathrm{O}_{5} / \mathrm{SiO}_{2}\right)$ as well as $\mathrm{TiO}_{2}$ layer- $\mathrm{V}_{2} \mathrm{O}_{5}$ layer were obtained, when no visible Si diffusion into the $\mathrm{V}_{2} \mathrm{O}_{5}$ layer was detected (within e.g. the RBS error limit). The correct film notation is the same as the nominal one, i.e. $\mathrm{TiO}_{2} / \mathrm{V}_{2} \mathrm{O}_{5} / \mathrm{SiO}_{2}$.

TABLE I

Effect of hydrogen charging on two selected films: $\mathrm{V}_{2} \mathrm{O}_{5} / \mathrm{TiO}_{2} / \mathrm{SiO}_{2}$ and $\mathrm{TiO}_{2} / \mathrm{V}_{2} \mathrm{O}_{5} / \mathrm{SiO}_{2}$. $\mathrm{H}(1)$ and $\mathrm{H}(2)$ denoted the first and second charging (each at $p=1$ bar, $T=300^{\circ} \mathrm{Cfor} 3 \mathrm{~h}$ ). $d(\mathrm{~nm})$ and $(\%)$ present respectively the layer-thickness of each layer and the percentage of each type of oxides. Layer (1) denotes the surface layer. $D(\mathrm{~nm})$ is the increased thickness of the film due to hydrogenation.

\begin{tabular}{|c|c|c|c|c|c|c|c|c|}
\hline $\mathrm{V}_{2} \mathrm{O}_{5} / \mathrm{TiO}_{2} / \mathrm{SiO}_{2}$ & Layer & $\begin{array}{c}\mathrm{V}_{2} \mathrm{O}_{5} \\
{[\%]}\end{array}$ & $\begin{array}{c}\mathrm{TiO}_{2} \\
{[\%]}\end{array}$ & $\begin{array}{l}\mathrm{VO}_{2} \\
{[\%]}\end{array}$ & $\begin{array}{l}\mathrm{SiO}_{2} \\
{[\%]}\end{array}$ & $\begin{array}{c}d \\
{[\mathrm{~nm}]}\end{array}$ & $\begin{array}{c}D \\
{[\mathrm{~nm}]}\end{array}$ & $\begin{array}{l}\text { Increased } \\
\text { thickness }\end{array}$ \\
\hline as-deposited & $\begin{array}{l}1 \\
2\end{array}$ & 100 & 85 & 9 & 6 & $\begin{array}{l}68 \\
54\end{array}$ & 122 & \\
\hline $\begin{array}{c}\text { hydrogenation-1 } \\
\text { H (1) }\end{array}$ & $\begin{array}{l}1 \\
2 \\
3\end{array}$ & 100 & $\begin{array}{l}63 \\
19\end{array}$ & $\begin{array}{l}26 \\
19\end{array}$ & $\begin{array}{l}11 \\
62\end{array}$ & $\begin{array}{l}62 \\
56 \\
13\end{array}$ & 131 & $7 \%$ \\
\hline $\begin{array}{c}\text { hydrogenation-2 } \\
\text { H (2) }\end{array}$ & $\begin{array}{l}1 \\
2 \\
3 \\
\end{array}$ & 100 & $\begin{array}{c}48 \\
7 \\
\end{array}$ & $\begin{array}{l}36 \\
18\end{array}$ & $\begin{array}{l}16 \\
75\end{array}$ & $\begin{array}{l}62 \\
37 \\
41 \\
\end{array}$ & 140 & $15 \%$ \\
\hline $\mathrm{TiO}_{2} / \mathrm{V}_{2} \mathrm{O}_{5} / \mathrm{SiO}_{2}$ & Layer & $\begin{array}{c}\mathrm{TiO}_{2} \\
{[\%]}\end{array}$ & $\begin{array}{c}\mathrm{V}_{2} \mathrm{O}_{5} \\
{[\%]}\end{array}$ & $\begin{array}{l}\mathrm{VO}_{2} \\
{[\%]} \\
\end{array}$ & $\begin{array}{c}\mathrm{SiO}_{2} \\
{[\%]} \\
\end{array}$ & $\begin{array}{c}d \\
{[\mathrm{~nm}]}\end{array}$ & $\begin{array}{c}D \\
{[\mathrm{~nm}]}\end{array}$ & $\begin{array}{l}\text { Increased } \\
\text { thickness }\end{array}$ \\
\hline as-deposited & $\begin{array}{l}1 \\
2\end{array}$ & 100 & 100 & & & $\begin{array}{c}113 \\
71\end{array}$ & 184 & \\
\hline $\begin{array}{c}\text { hydrogenation-1 } \\
\text { H (1) }\end{array}$ & $\begin{array}{l}1 \\
2 \\
3\end{array}$ & 100 & 100 & 15 & 85 & $\begin{array}{c}112 \\
58 \\
14\end{array}$ & 184 & $0 \%$ \\
\hline $\begin{array}{c}\text { hydrogenation- } 2 \\
\text { H (2) }\end{array}$ & $\begin{array}{l}1 \\
2 \\
3\end{array}$ & 100 & 0 & $\begin{array}{l}94 \\
15\end{array}$ & $\begin{array}{c}6 \\
85\end{array}$ & $\begin{array}{c}111 \\
47 \\
29\end{array}$ & 187 & $2 \%$ \\
\hline
\end{tabular}




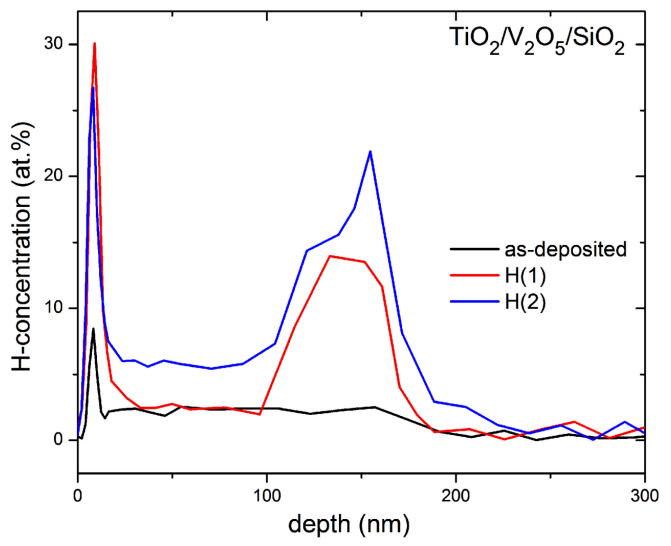

Fig. 2. The hydrogen profile determined by ${ }^{15} \mathrm{~N}-\mathrm{NRA}$ for $\mathrm{TiO}_{2} / \mathrm{V}_{2} \mathrm{O}_{5} / \mathrm{SiO}_{2}$ film. Hydrogen assists a complete $\mathrm{V}_{2} \mathrm{O}_{5}-\mathrm{VO}_{2}$ transition and hydrogen concentration of $15-20$ at.\% stores in this layer.

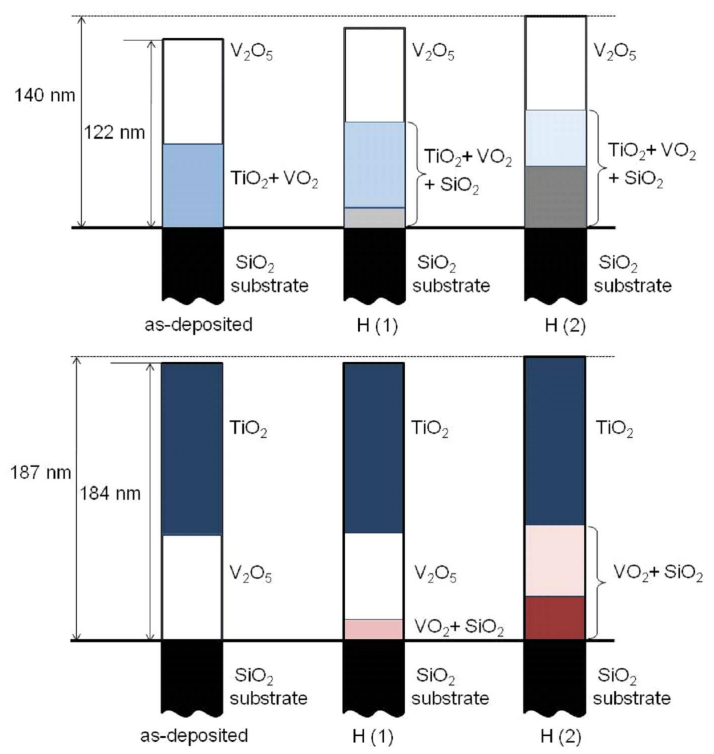

Fig. 3. Illustration of the influence of hydrogenation on the structure and composition of $\mathrm{V}_{2} \mathrm{O}_{5} / \mathrm{Ti}_{2} / \mathrm{SiO}_{2}$ film and $\mathrm{TiO}_{2} / \mathrm{V}_{2} \mathrm{O}_{5} / \mathrm{SiO}_{2}$ film. The surface $\mathrm{V}_{2} \mathrm{O}_{5}$ layer was well preserved upon hydrogen charging, while for the $\mathrm{TiO}_{2} / \mathrm{V}_{2} \mathrm{O}_{5} / \mathrm{SiO}_{2}$ film hydrogen supports a complete $\mathrm{V}_{2} \mathrm{O}_{5}-\mathrm{VO}_{2}$ transition in the film.

We have performed the hydrogen charging on films with $\mathrm{V}_{2} \mathrm{O}_{5}$ and/or $\mathrm{TiO}_{2}$ as the surface layer. Most of them were charged by hydrogen twice (denoted as $\mathrm{H}(1)$ and $\mathrm{H}(2)$ in Table I and figures). The most visible hydrogen effect on the film structure and properties were observed on the $\mathrm{TiO}_{2} / \mathrm{MO}_{2} / \mathrm{SiO}_{2}$ and $\mathrm{V}_{2} \mathrm{O}_{5} / \mathrm{TiO}_{2} / \mathrm{SiO}_{2}$ with a film thickness of $122 \mathrm{~nm}$ and $184 \mathrm{~nm}$, respectively. The $\mathrm{N}-15$ experiments have been performed on these films to determine the hydrogen content in different layers upon hydrogen charging. However, due to some technical difficulties (e.g. the sample was broken after the second hydrogen charging or its size was not suitable for the measurements), we could get reliable results only for $\mathrm{TiO}_{2} / \mathrm{V}_{2} \mathrm{O}_{5} / \mathrm{SiO}_{2}$ film, as shown in Fig. 2. The N-15 results are in a good agreement with those from the RBS analysis. Namely, the hydrogen diffuses through the $\mathrm{TiO}_{2}$ and does not accumulate there, indicating by a very low hydrogen content in the thickness range down to about $100 \mathrm{~nm}$ with respect to the film surface, i.e. the thickness of $\mathrm{TiO}_{2}$ layer (except of the residual amount of hydrogen on the very surface layer). The hydrogen reaches an average value of about $15-20$ at.\% at the thickness range of $100-180 \mathrm{~nm}$, i.e. in the vanadium oxide layer.

The change in the layer thickness and composition upon hydrogen charging of these two films were listed in Table I. We notice here that the relative change between different layers is very small which did not lead to visible changes in e.g. RBS spectra. For a clear demonstration of the hydrogen effect, we construct the film diagram shown in Fig. 3. The results indicate that:

- For the $\mathrm{V}_{2} \mathrm{O}_{5} / \mathrm{MO}_{2} / \mathrm{SiO}_{2}$ film, a large increase of the total film thickness, up to $15 \%$ of its original value, was gained after hydrogen charging of $6 \mathrm{~h}$. Hydrogen charging leads to a large decrease of the $\mathrm{TiO}_{2}$ portion and a large increase of the $\mathrm{SiO}_{2}$ portion in the mixed $\mathrm{MO}_{2}$ layer revealing a strong $\mathrm{Si}$ diffusion from the substrate. The large increase of the total film thickness is in fact due to a large thickness increase of such a mixed $\mathrm{TiO}_{2}-\mathrm{VO}_{2}-\mathrm{SiO}_{2}$ layers.

- For the $\mathrm{TiO}_{2} / \mathrm{V}_{2} \mathrm{O}_{5} / \mathrm{SiO}_{2}$ film, the total film thickness does not change much; it increases only by $2 \%$ upon hydrogen charging. However, in this case, a very large reduction of $\mathrm{V}_{2} \mathrm{O}_{5}$ is observed. After $6 \mathrm{~h}$ charging, a complete transition of $\mathrm{V}_{2} \mathrm{O}_{5}$ into $\mathrm{VO}_{2}$ was obtained.

- The hydrogen storage up to 20 at. $\%$ in the $\mathrm{TiO}_{2} / \mathrm{V}_{2} \mathrm{O}_{5} / \mathrm{SiO}_{2}$ film seems to be related to $\mathrm{VO}_{2}$ layer, i.e. during and/or after $\mathrm{V}_{2} \mathrm{O}_{5}-\mathrm{VO}_{2}$ transition.

- A large Si diffusion from the substrate into the films was observed. We notice here that the films were heated up to $300^{\circ} \mathrm{C}$ during hydrogen charging which may be the reason of such enhanced Si diffusion. However, the Si diffusion was much enhanced in the case of deposition of $\mathrm{TiO}_{2}$ layer on $\mathrm{SiO}_{2}$ substrate, while such $\mathrm{Si}$ diffusion can be limited for $\mathrm{V}_{2} \mathrm{O}_{5}$ film deposition (sharp interface without Si diffusion) as well as during the hydrogen charging procedure.

- For both films, the stoichiometric $\mathrm{TiO}_{2}$ and/or $\mathrm{V}_{2} \mathrm{O}_{5}$ layer was well preserved on the film surface: the layer thickness is almost unchanged upon hydrogen charging. Thus the swelling effect seems to be related to $\mathrm{TiO}_{2}$, since a large thickness increase was obtained for the mixed $\mathrm{TiO}_{2}-\mathrm{VO}_{2}-\mathrm{SiO}_{2}$ layer (i.e. consisting of $\mathrm{TiO}_{2}$ ), whereas the mixed $\mathrm{VO}_{2}-\mathrm{SiO}_{2}$ layer does not lead to a visible film swelling. 


\section{Hydrogen storage in $\mathrm{Ti}-\mathrm{V}-\mathrm{Ni}$ films}

In order to get a deeper understanding of the hydrogen absorption capacity, we extend our investigations to other thin film system consisting of $\mathrm{Ti}$ and $\mathrm{V}$, such as $\mathrm{Ti}-$ $\mathrm{V}$ system with Ni-doping. Vanadium and nickel plates were placed on titanium target to obtain $\mathrm{Ti}: \mathrm{V}: \mathrm{Ni}$ ratio of 1:1:1 and 0.6:0.1:0.3, respectively. Sputtering time of $180 \mathrm{~s}$ was acquired to obtain the film with a nominal thickness of $150 \mathrm{~nm}$ on $\mathrm{Si}(111)$ and $\mathrm{SiO}_{2}$ substrate, respectively. Both two samples were charged with hydrogen at pressure of 1 bar and at temperature of $300^{\circ} \mathrm{C}$ for $3 \mathrm{~h}$. For those two films, visible changes were revealed in the RBS spectra.

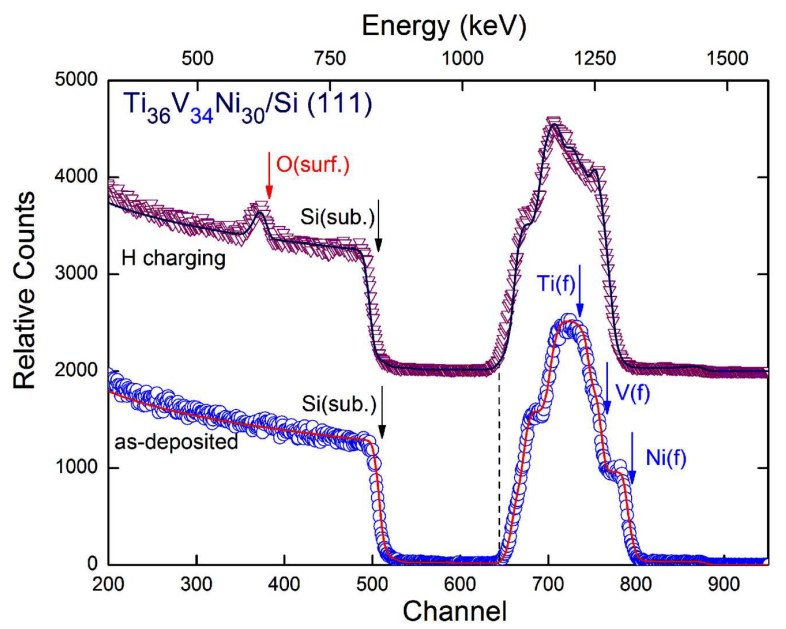

Fig. 4. Random RBS (markers) and SIMNRA (lines) simulated spectra for $151 \mathrm{~nm} \mathrm{Ti}_{36} \mathrm{~V}_{34} \mathrm{Ni}_{30} / \mathrm{Si}(111)$ film before and after hydrogen charging. The curves were normalized and shifted for a clarity. (f) labels the signal in the film, while (sub.) for that from the substrate. The surface oxidization upon hydrogen charging is revealed by an appearance of oxygen signal $(\mathrm{O}$ (surf. $))$. The vertical dotted line indicates that the film thickness (or the peak width) does not change upon hydrogenation.

We show in Figs. 4 and 5 the measured and simulated RBS spectra for the two Ti-V-Ni films before and after hydrogen charging. Details of layer composition and thickness estimated from SIMNRA for each layer of each film before and after hydrogen charging are given in Table II. The RBS spectrum of as-deposited $\mathrm{Ti}-\mathrm{V}-$ $\mathrm{Si} / \mathrm{Si}(111)$ film, shown in Fig. 4, is characterized by a large and wide peak at energy range of 1050 and $1300 \mathrm{keV}$ corresponding to $\mathrm{Ti}_{-}, \mathrm{V}$ - and Ni signals from the film (i.e. the energy of $\mathrm{He}^{+}$ions backscattered from a binary collision with the $\mathrm{Ti}-, \mathrm{V}-$ and $\mathrm{Ni}$ atoms in the film). The composition of each element is quite similar in the film: $36 \mathrm{wt} \% \mathrm{Ti}, 34 \mathrm{wt} \% \mathrm{~V}$ and $30 \mathrm{wt} \% \mathrm{Ni}$, or $\mathrm{Ti}_{36} \mathrm{~V}_{34} \mathrm{Ni}_{30} / \mathrm{Si}(111)$, i.e. quite close to the nominal ratio $(1: 1: 1)$. Besides, the film thickness is estimated to be $151 \mathrm{~nm}$, i.e. equal to the nominal value. The molar mass of such 3 elements are very close to each other $(m(\mathrm{Ni})=58.7 \mathrm{~g}, m(\mathrm{~V})=50.9 \mathrm{~g}, m(\mathrm{Ti})=47.8 \mathrm{~g})$. Thus

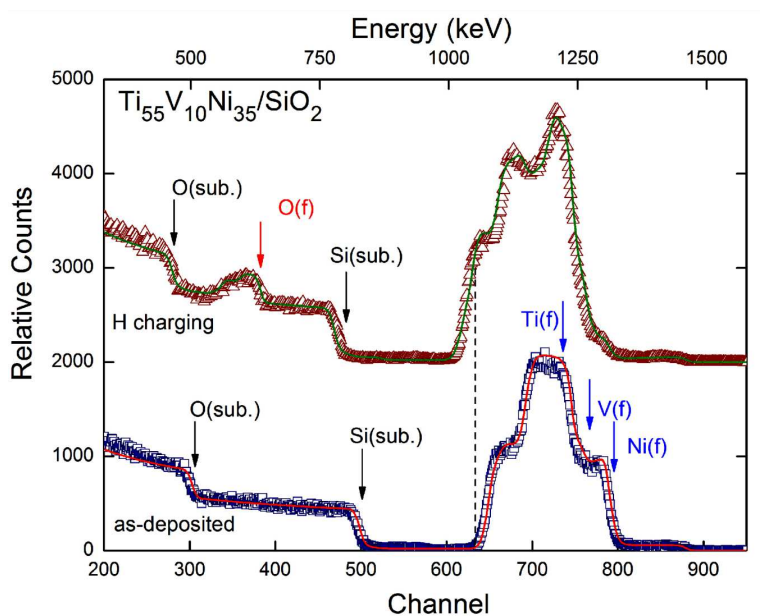

Fig. 5. Random RBS (markers) and SIMNRA (lines) simulated spectra for $178 \mathrm{~nm} \mathrm{Ti}_{55} \mathrm{~V}_{10} \mathrm{Ni}_{35} / \mathrm{SiO}_{2}$ film before and after hydrogen charging. The notation (f) and (sub.) are the same as those in Fig. 4. The presence of the oxygen in the entire film upon hydrogen charging is indicated by $\mathrm{O}(\mathrm{f})$. The vertical dotted line indicates that the film thickness (or the peak-width) increases upon hydrogenation.

the "combined" signals from those 3 elements formed the wide peak with some fine structures (e.g. 2 small peaks at the two sides of a wide peak located around $1200 \mathrm{keV}$ ). For such a sample, the Si-edge from the Si substrate locates at energy around $850 \mathrm{keV}$.

Hydrogen charging leads to surface oxidation of the film revealed by an appearance of a quite sharp O-peak at energy of $620 \mathrm{keV}$. The film structure can be considered to consist of 2 different regions: (1) the oxidized layer with a total thickness of $48 \mathrm{~nm},(2)$ the main part of the film is the pure metal layers of a total thickness of $103 \mathrm{~nm}$. A surprising fact is that the total thickness of the $\mathrm{Ti}-\mathrm{V}-$ $\mathrm{Ni} / \mathrm{Si}(111)$ film does not change by hydrogen charging. Despite of the change of the peak-shape related to some re-arrangement of the metal atoms in the films (revealed by the composition change in different sublayers), the peak-width in the RBS spectra is similar for both asdeposited film and that after hydrogen charging. It was illustrated by the vertical dotted-line in the figure: the $\mathrm{Ti}-\mathrm{V}-\mathrm{Ni}$ peak ends at the same energy value.

We notice here that the hydrogen charging has been carried out at $300{ }^{\circ} \mathrm{C}$ for a quite long time (of $3 \mathrm{~h}$ ). The significant change of the element-ratio upon hydrogen charging, in our opinion, is rather related to the diffusion process at elevate temperatures. A highest $\mathrm{Ni}$ concentration was found on the top sublayer of the pure metal layer (64 at.\%). In the deeper parts of the film, nickel concentration did not change (35 at.\%). The interdiffusion is found between $\mathrm{Ti}$ and $\mathrm{V}$, in which the top sublayer (layer 3) consists of more Ti (21 at.\%) and less $\mathrm{V}$ (15 at.\%), while for the bottom sublayer (layer 5 , located directly on the Si substrate) it is opposite, i.e. it consists of less $\mathrm{Ti}$ (10 at.\%) and more V (50 at.\%). 


\section{TABLE II}

Effect of hydrogen charging on the $\mathrm{V}-\mathrm{Ti}-\mathrm{Ni}$ films deposited on $\mathrm{Si}$ and $\mathrm{SiO}_{2}$ substrates. $d(\mathrm{~nm})$ and $(\%)$ present respectively the layer-thickness of each layer and the percentage of each type of oxides. Layer (1) denotes the surface layer. $D(\mathrm{~nm})$ is the increased thickness of the film due to hydrogenation.

\begin{tabular}{|c|c|c|c|c|c|}
\hline $\mathrm{Ti}-\mathrm{V}-\mathrm{Ni} / \mathrm{Si}$ & Layer & $\begin{array}{c}d \\
{[\mathrm{~nm}]}\end{array}$ & $\begin{array}{c}D \\
{[\mathrm{~nm}]}\end{array}$ & $\begin{array}{l}\text { Increased } \\
\text { thickness }\end{array}$ & \\
\hline as-deposited & 1 & $\mathrm{Ti}_{36} \mathrm{~V}_{34} \mathrm{Ni}_{30} / \mathrm{Si}$ & 151 & 151 & \\
\hline $\begin{array}{c}\text { Hydrogen } \\
\text { charging }\end{array}$ & $\begin{array}{l}1 \\
2 \\
3 \\
4 \\
5\end{array}$ & $\begin{array}{c}88 \% \mathrm{TiO}_{2}+9 \% \mathrm{VO}_{2}+4 \% \mathrm{NiO}_{2} \\
14 \%(\mathrm{Ti}, \mathrm{V}, \mathrm{Ni}) \mathrm{O}_{2}+86 \%(\mathrm{TiVNi}) \\
\mathrm{Ti}_{21} \mathrm{~V}_{15} \mathrm{Ni}_{64} \\
\mathrm{Ti}_{19} \mathrm{~V}_{44} \mathrm{Ni}_{35} \\
\mathrm{Ti}_{10} \mathrm{~V}_{50} \mathrm{Ni}_{35}\end{array}$ & $\begin{array}{l}29 \\
19 \\
26 \\
48 \\
29\end{array}$ & 151 & $0 \%$ \\
\hline $\mathrm{Ti}-\mathrm{V}-\mathrm{Ni} / \mathrm{SiO}_{2}$ & Layer & $\begin{array}{c}d \\
{[\mathrm{~nm}]}\end{array}$ & $\begin{array}{c}D \\
{[\mathrm{~nm}]}\end{array}$ & $\begin{array}{l}\text { Increased } \\
\text { thickness }\end{array}$ & \\
\hline as-deposited & 1 & $\mathrm{Ti}_{55} \mathrm{~V}_{10} \mathrm{Ni}_{35} / \mathrm{SiO}_{2}$ & 178 & 178 & \\
\hline $\begin{array}{c}\text { Hydrogen } \\
\text { charging }\end{array}$ & $\begin{array}{l}1 \\
2 \\
3 \\
4 \\
5 \\
6\end{array}$ & $\begin{array}{c}88 \% \mathrm{TiO}_{2}+12 \% \mathrm{NiO}_{2} \\
38 \% \mathrm{TiO}_{2}+45 \% \mathrm{VO}_{2}+17 \% \mathrm{NiO}_{2} \\
25 \%(\mathrm{TiVNi})+75 \%(\mathrm{Ti}, \mathrm{V}, \mathrm{Ni}) \mathrm{O}_{2} \\
70 \%(\mathrm{TiVNi})+30 \%(\mathrm{Ti}, \mathrm{V}, \mathrm{Ni}) \mathrm{O}_{2} \\
85 \%(\mathrm{TiVNi})+15 \% \mathrm{SiO}_{2} \\
78 \%(\mathrm{TiVNi})+22 \% \mathrm{SiO}_{2}\end{array}$ & $\begin{array}{l}17 \\
30 \\
58 \\
23 \\
54 \\
28\end{array}$ & 210 & $17 \%$ \\
\hline
\end{tabular}

The RBS spectrum of as-deposited $\mathrm{Ti}-\mathrm{V}-\mathrm{Ni} / \mathrm{SiO}_{2}$ film (Fig. 5) is quite similar to that of $\mathrm{Ti}-\mathrm{V}-\mathrm{Ni} / \mathrm{Si}(111)$ film, i.e. with a wide peak at energy range of $1050 \mathrm{keV}$ and $1300 \mathrm{keV}$ corresponding to the Ti-, V- and Ni signal from the film, the Si-edge and the oxygen signal from the $\mathrm{SiO}_{2}$ substrate locates respectively at energy around $850 \mathrm{keV}$ and $500 \mathrm{keV}$, located on the Si-plateau (from $\mathrm{Si}$ substrate). In this case, the element composition is in a good agreement to the nominal one: $55 \mathrm{wt} \% \mathrm{Ti}$, $10 \mathrm{wt} \% \mathrm{~V}$ and $35 \mathrm{wt} \% \mathrm{Ni}$, or $\mathrm{Ti}_{55} \mathrm{~V}_{10 \mathrm{Ni}_{35}} / \mathrm{SiO}_{2}$. However, the film thickness is estimated to be $178 \mathrm{~nm}$, i.e. larger than the nominal thickness.

Unlike the film deposited on the $\mathrm{Si}(111)$ substrate, the entire film deposited on $\mathrm{SiO}_{2}$ was oxidized upon hydrogen charging. The oxygen signal from the entire oxidized film and from the $\mathrm{SiO}_{2}$ substrate leads to some fine structure in the RBS spectrum between $400 \mathrm{keV}$ and $700 \mathrm{keV}$ consisting of the broader O-peak from the film and the smoother O-edge from the substrate. The film structure after hydrogen charging can be divided into 3 main regions: (1) on the surface there is the entire oxidized layer (with a thickness of $47 \mathrm{~nm}$ ), (2) the mixed metal $\mathrm{Ti}-\mathrm{V}-\mathrm{Ni}$ and their oxide layer $(81 \mathrm{~nm})$ and $(3)$ the interface layer consisting of pure metals and $\mathrm{SiO}_{2}(82 \mathrm{~nm})$. As a result of both surface oxidization and oxygen diffusion out from the substrate into the film, the oxygen is present throughout the entire film. Upon hydrogen charging, despite of some difficulties in obtaining the precise estimation of each metal content in the film, the total metal $(\mathrm{M}=(\mathrm{Ti}+\mathrm{V}+\mathrm{Ni})$ content can be easily estimated, when we assumed a formation of only metal dioxide $\left(\mathrm{MO}_{2}\right)$. Similar to $\mathrm{Ti}-\mathrm{V}-\mathrm{Ni} / \mathrm{Si}(111)$ film, we distributed the significant change of the element-ratio and interdiffusion upon hydrogen charging to the diffusion process of metals at elevated temperatures during the hydrogen charging process.

The total thickness of the $\mathrm{Ti}-\mathrm{V}-\mathrm{Ni} / \mathrm{SiO}_{2}$ film increased by $17 \%$ due to hydrogen charging (i.e. from $178 \mathrm{~nm}$ to $210 \mathrm{~nm}$ ). It is illustrated by the vertical dotted-line in the figure: the $\mathrm{Ti}-\mathrm{V}-\mathrm{Ni}$ peak after hydrogenation ends at a lower energy value, i.e. the peak-width is much larger in this case.

We notice here that from our study on $\mathrm{TiO}_{2}-\mathrm{V}_{2} \mathrm{O}_{5}$ film system we suggested that the large swelling effect is related to the mixed $\mathrm{TiO}_{2}-\mathrm{VO}_{2}-\mathrm{SiO}_{2}$ layer (15\%) upon hydrogen charging. Our obtained results for $\mathrm{Ti}-\mathrm{V}-\mathrm{Ni}$ system gives a strong support for this suggestion. Namely, the Ni content is similar in both 2 films. A larger thickness increase was observed for the film with a larger $\mathrm{Ti}$ content (i.e. $\mathrm{Ti}_{55} \mathrm{~V}_{10} \mathrm{Ni}_{35} / \mathrm{SiO}_{2}$ ) and thus a larger portion of $\mathrm{TiO}_{2}$ in the layer upon hydrogen charging.

Hydrogen profile determined from $\mathrm{N}-15$ experiments for $\mathrm{Ti}-\mathrm{V}-\mathrm{Ni} / \mathrm{Si}(111)$ film is presented in Fig. 6. Before hydrogen charging, $\mathrm{Ti}-\mathrm{V}-\mathrm{Ni}$ layer reveals small amount of hydrogen $(\approx 4$ at.\%) distributed quite homogeneously within the whole film up to $100 \mathrm{~nm}$ deep from the film surface. On the surface (up to the thickness of 10-15 nm) a quite high concentration of 15 at.\% of hydrogen is found. Hydrogen charging causes an enormous increase of hydrogen amount up to 32 at.\% in the film. However, the hydrogen profile reveals that the hydrogen gathers mostly in the deepness of the range of $50-100 \mathrm{~nm}$, i.e. in the deep layer consisting of pure $\mathrm{Ti}-\mathrm{V}-\mathrm{Ni}$ metal (layer 3-5, Table II). 


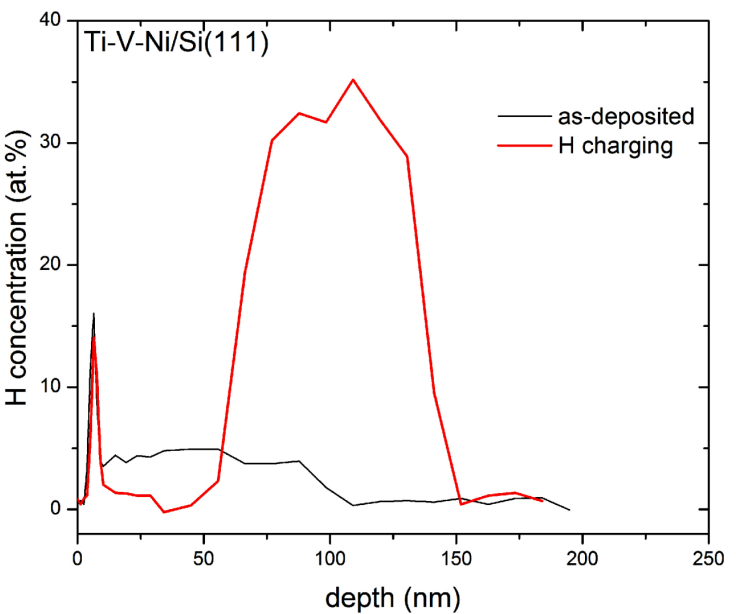

Fig. 6. Hydrogen profiles of $\mathrm{Ti}-\mathrm{V}-\mathrm{Ni}$ layer on $\mathrm{Si}(111)$ before (as-deposited) and after hydrogen charging revealing a large hydrogen storage $(\approx 32$ at.\%) in the deep metallic $\mathrm{Ti}-\mathrm{V}-\mathrm{Ni}$ layer.

The hydrogen profile obtained by N-15 technique for the $\mathrm{Ti}-\mathrm{V}-\mathrm{Ni} / \mathrm{SiO}_{2}$ film is shown in Fig. 7. Similarly, before hydrogen charging an amount of hydrogen up to $\approx 4$ at.\% is homogeneously distributed in the film. After hydrogen charging process, a significant increase of hydrogen concentration is revealed. Hydrogen is accumulated deeply in the film, at the deepness (from the film surface) of $100-200 \mathrm{~nm}$, corresponding to the region consisting of layers with a high $\mathrm{Ti}-\mathrm{V}-\mathrm{Ni}$ content ( $>70 \%$, layer $4-6$, Table II). However, the hydrogen amount reaches only 28 at.\%, i.e. lower than that in the film deposited on $\mathrm{Si}(111)$ substrate.

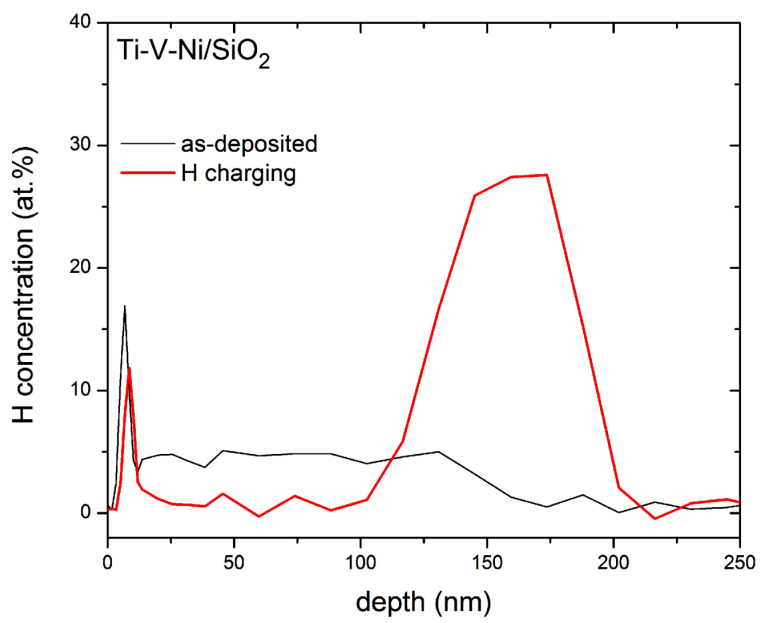

Fig. 7. Hydrogen profile of $\mathrm{Ti}-\mathrm{V}-\mathrm{Ni}$ layer deposited on $\mathrm{SiO}_{2}$ before (as deposited) and after hydrogen charging. A quite high hydrogen storage rate $(\approx 28$ at.\%) was also revealed in the deep metallic $\mathrm{Ti}-\mathrm{V}-\mathrm{Ni}$ layer.

We summarized our obtained results on $\mathrm{Ti}-\mathrm{V}-\mathrm{Ni}$ film series as follows:
- The film surface was oxidized upon hydrogen charging and it consists mostly of $\mathrm{TiO}_{2}$. The results obtained on $\mathrm{Ti}-\mathrm{V}-\mathrm{Ni}$ films also confirm that hydrogen can diffuse through the oxide layer without gathering there.

- A large hydrogen storage (28-32 at.\%) was found in the pure metallic $\mathrm{Ti}-\mathrm{V}-\mathrm{Ni}$ layers. The hydrogen storage in the pure metal layer does not lead to any enlargement of the film thickness. It may indicate that the metal layers can have more interstitial sites for hydrogen and that hydrogen storage does not need any lattice expansion.

- The higher hydrogen storage is found in the film with a higher $\mathrm{Ti}$ content indicating that titanium seems to have a higher hydrogen absorption capacity (than vanadium). More experiments are needed to verify the titanium and vanadium hydrogen absorption ability.

- The large swelling effect is attributed to the $\mathrm{TiO}_{2}$ : the layer consisting of a larger portion of $\mathrm{TiO}_{2}$ always shows a larger thickness increase. This suggestion was supported by the observations on $\mathrm{TiO}_{2}-\mathrm{V}_{2} \mathrm{O}_{5}$ film series: a larger swelling effect was found for the mixed $\mathrm{TiO}_{2}-\mathrm{VO}_{2}-\mathrm{SiO}_{2}$ layer than that of $\mathrm{VO}_{2}-\mathrm{SiO}_{2}$ one.

We notice here also that, despite of a big difference in $\mathrm{Ti}$ and $\mathrm{V}$ concentration, the $\mathrm{Ni}$ concentration in both films is similar. Thus we cannot draw any conclusion about the role of $\mathrm{Ni}$ in the $\mathrm{Ti}-\mathrm{V}-\mathrm{Ni}$ film system.

\section{Concluding remarks}

The most important findings of our investigations on 3 different thin film systems consisting of $\mathrm{Ti}, \mathrm{V}$ and their oxides are: (1) a largest hydrogen amount (with hydrogen content up to 50 at.\%) can be stored in the Ti film or in the thin film systems consisting of pure $\mathrm{Ti}$ layer, (2) palladium could act as a good catalyst for hydrogen diffusion into the films and leads to a large enhancement of hydrogen storage, (3) hydrogen supports the $\mathrm{V}_{2} \mathrm{O}_{5}$ $\mathrm{VO}_{2}$ transition and could be also stored in the $\mathrm{VO}_{2}$ layer $(\approx 20$ at.\%) in some cases, (4) a large hydrogen storage $(\approx 30$ at.\%) can be also in $\mathrm{Ti}-\mathrm{V}-\mathrm{Ni}$ films.

Our results reveal that the Ti, V and their oxides-based thin films could be good candidates for hydrogen storage materials.

\section{Acknowledgments}

The authors highly acknowledged the great help and fruitful cooperation of A. Brudnik, S. Flege, C. Schmitt, D. Rogalla and H.-W. Becker. We acknowledge the support of the Czech-Polish cooperation (Czech-Polish project 7AMB14PL036 (9004/R14/R15). N-T.H.K.-N. acknowledged the financial support by the European Regional Development Fund under the Infrastructure and Environment Programme. 


\section{References}

[1] Metal Hydrides: Fundamentals and Applications, Eds. M.V.C. Sastri, B. Viswanathan, S. Srinivasa Murthy, Narosa Publ. House, New Delhi 1998.

[2] Handbook of Hydrogen Storage: New Materials for Future Energy Storage, Ed. M. Hirscher, Wiley-VCH, 2010.

[3] S. Orimo, H. Fujii, Appl. Phys. A 72, 167 (2001).

[4] M. Zhu, C.H. Pene, L.Z. Ouyang, Y.Q. Tong, J. Alloys Comp. 426, 316 (2006).

[5] W.Y. Li, C. Li, H. Ma, J. Chen, J. Am. Chem. Soc. 129, 6710 (2007).

[6] A. Brudnik, M. Bucko, M. Radecka, A. TrenczekZajac, K. Zakrzewska, Vacuum 82, 936 (2008) and references therein.

[7] K. Drogowska, Z. Tarnawski, A. Brudnik, E. Kusior, M. Sokołowski, K. Zakrzewska, A. Reszka, N.T.H. Kim-Ngan, A.G. Balogh, Mater. Res. Bull. 47, 296 (2012).

[8] N.-T.H. Kim-Ngan, A.G. Balogh, J.D. Meyer, J. Brötz, S. Hummelt, M. Zając, T. Ślęzak, J. Korecki, Surf. Sci. 602, 2358 (2008).

[9] N.-T.H. Kim-Ngan, A.G. Balogh, J.D. Meyer, J. Brötz, M. Zając, T. Ślęzak, J. Korecki, Surf. Sci. 603, 1175 (2009).

[10] A. Fujishima, K. Honda, Nature 238, 37 (1972).

[11] A. Fujishima, T.N. Rao, D.A. Tryk, J. Photochem. Photobiol. C Photochem. Rev. 1, 1 (2000).

[12] A.L. Linsebigler, G. Lu, J.T. Yates Jr., Chem. Rev. 95, 735 (1995).

[13] M. Grätzel, Nature 414, 338 (2001) and references therein.

[14] O.K. Varghese, D. Gong, M. Paulose, K.G. Ong, C.A. Grimes, Sens. Actuat. B 93, 338 (2003).

[15] A. Fujishima, X. Zhang, D.A. Tryk, Surf. Sci. Rep. 63, 515 (2008).

[16] M.A. Henderson, Surf. Sci. Rep. 66, 185 (2011).

[17] M-I. Baraton, The Open Nanosci. J. 5, 64 (2011).

[18] A. Fujishima, X. Zhang, D.A. Tryk, Int. J. Hydrogen En. 32, 2664 (2007)

[19] R. Asahi, T. Morikawa, T. Ohwaki, K. Aoki, Y. Taga, Science 293, 269 (2001).

[20] L.R. Sheppard, T. Bak, J. Nowotny, M.K. Nowotny, Int. J. Hydrogen En. 32, 2660 (2007).

[21] M.M. Islam, T. Bredow, A. Gerson, Phys. Rev. B 76, 045217 (2007)
[22] K. Hashimoto, H. Irie, A. Fujishima, Jap. J. Appl. Phys. 44, 8269 (2005).

[23] B. Murphy, P.R.F. Barnes, L.K. Randeniya, I.C. Plumb, I.E. Grey, M.D. Horne, J.A. Glasscock, Int. J. Hydrogen En. 31, 1999 (2006).

[24] J. Nowotny, T. Bąk, M.K. Nowotny, L.R. Sheppard, Int. J. Hydrogen En. 32, 2609 (2007).

[25] S.-H. Lim, J. Luo, Z. Zhong, W. Ji, J. Lin, Inorg Chem. 44, 4124 (2005).

[26] P. Pillai, K.S. Raja, M. Misra, J. Power Sources 161, 524 (2006).

[27] M. Ni, M.K.H. Leung, D.Y.C. Leung, K. Sumathy, Renew. Sustain. En. Rev. 11, 401 (2007).

[28] X. Hu, G. Li, J.C. Yu, Langmuir 26, 3031 (2010).

[29] D.V. Bavykin, A.A. Lapkin, P.K. Plucinski, J.M. Friedrich, F.C. Walsh, J. Phys. Chem. B 109, 19422 (2005).

[30] Z. Li, D. Ding, C. Ning, Nanoscale Res. Lett. 8, 25 (2013).

[31] Z. Li, D. Ding, Q. Liu, C. Ning, Sensors 13, 8393 (2013).

[32] Z. Tarnawski, N.-T.H. Kim-Ngan, K. Zakrzewska, K. Drogowska, A. Brudnik, A.G. Balogh, R. Kužel, L. Havela, V. Sechovsky, Adv. Nat. Sci. Nanosci. Nanotechnol. 4, 025004 (2013).

[33] K. Drogowska, S. Flege, C. Schmitt, D. Rogalla, H.W. Becker, N.-T.H. Kim-Ngan, A. Brudnik, Z. Tarnawski, K. Zakrzewska, M. Marszalek, A.G. Balogh, Adv. Mater. Sci. Eng. 2012, 269603 (2012).

[34] P. Rosaiah, O.M. Hussain, Adv. Nanomater. Nanotechnol. Springer Proc. Phys. 143, 485 (2013).

[35] L.T. Zhang, J. Song, Q.F. Dong, S.T. Wu, Adv Mater. Res. 79-82, 931 (2009).

[36] A. Talledo, H. Valdivia, C. Benndorf, J. Vac. Sci. Technol. A 21, 1494 (2003).

[37] D. Honicke, J. Xu, J. Phys. Chem. 92, 4699 (1988).

[38] Y.C. Xie, Y.Q. Tang, Adv. Catal. 37, 1 (1990).

[39] See e.g. G. Centi, Appl. Catal. A General 147, 267 (1996).

[40] N.R. Mlyuka, G.A. Niklasson, C.G. Granqvist, Solar Energy Mater. Solar Cells 93, 1685 (2009).

[41] Z. Tarnawski, K. Zakrzewska, N.-T.H. Kim-Ngan, M. Krupska, S. Sowa, K. Drogowska, L. Havela, A.G. Balogh, Adv. Nat. Sci. Nanosci. Nanotechnol. 6, 013002 (2015) 